\title{
New Approach to Synthesis of Silica with Chemically Bound Guanidine Hydrochloride for Preconcentration of Metal Ions
}

\author{
Arsentii D. Dadashev1, Valentyn A. Tertykh¹, Elina S. Yanovska², Karolina V. Yanova ${ }^{3}$ \\ ${ }^{1}$ Chuiko Institute of Surface Chemistry of National Academy of Sciences of Ukraine, Kyiv, Ukraine \\ ${ }^{2}$ Chemistry Department of Kyiv National Taras Shevchenko University, Kyiv, Ukraine \\ ${ }^{3}$ Ukrainian State University of Chemical Engineering, Dnipropetrovs'k, Ukraine \\ Email: fyong@mail.ru
}

Received 15 February 2016; accepted 3 May 2016; published 6 May 2016

Copyright (C) 2016 by authors and Scientific Research Publishing Inc.

This work is licensed under the Creative Commons Attribution International License (CC BY).

http://creativecommons.org/licenses/by/4.0/

cC) (i) Open Access

\begin{abstract}
Guanidine hydrochloride was chemically bonded to surface of modified silica by means of condensation with grafted amino groups. Ion-exchanging and complexing properties of the obtained adsorbent have been studied with respect to cations of $\mathrm{Zn}$ (II), $\mathrm{Cu}$ (II), $\mathrm{Pb}$ (II), $\mathrm{Cd}(\mathrm{II}), \mathrm{Co}$ (II) and metalcontaining oxoanions of $\mathrm{W}(\mathrm{VI}), \mathrm{Mo}(\mathrm{VI}), \mathrm{Cr}(\mathrm{VI}), \mathrm{V}(\mathrm{V})$. Optimum conditions for quantitative extraction of the studied ions were determined. The structure and composition of Co(II) and Cu(II) complexes on the surface of the synthesized adsorbent have been investigated. The possibility of quantitative determination of cobalt(II) and copper(II) trace amounts after their preconcentration by the synthesized adsorbent was demonstrated.
\end{abstract}

\section{Keywords}

Silica, Guanidine Hydrochloride, Immobilization, Adsorption, Cations and Oxoanions of Transition Metals

\section{Introduction}

Surface immobilized silicas are widely used in solid-phase extraction, concentration and further quantitative analysis of ions and molecules. Various ligands, which can form ion-exchanged, coordinated, chemisorbed or molecular complexes with appropriate analytes, are usually used as surface modifiers [1]-[7]. Immobilization of compounds with amphiphilic properties has attracted considerable interest. In our previous studies [8]-[10] it was shown that silicas chemically modified with polyhexamethyleneguanidine and its carboxyl-containing 
derivatives exhibit good adsorption properties with respect to a number of transition metals cations and metalcontaining oxoanions. These adsorbents could quantitatively extract Zn(II), Cu(II), Fe(III), W(VI) ions and Mo-, V- and Cr-containing oxoanions from aqueous solutions over a wide concentration range. Such adsorption characteristics are caused by the presence of guanidyl groups in polymer chain of polyhexamethyleneguanidine. Depending on experimental conditions the guanidine-containing polymers may have an excess positive charge on the nitrogen atom or behave similarly typical amino compounds. However, at the usage of polymers immobilized on mineral surfaces, the role of diffusion factors is increased because such adsorbents can demonstrate their maximum sorption capacity only at full deployment of polymer chains under the influence of the solvent. There are also significant difficulties of the polymer transporting into pores of the silica matrix. In this respect, it was supposed that the modified silica with grafted layer of monomeric guanidine must have the better kinetic adsorption characteristics. However, data about methods of synthesis of such type modified silicas and their adsorption properties are currently unknown. We have taken into account the fact that synthesis of polyhexamethyleneguanidine is usually implemented via the condensation reaction of guanidine hydrochloride with hexamethylenediamine [11].

Therefore, we can expect that silica with grafted layer of guanidyl groups can be prepared by means of the similar condensation reaction of guanidine hydrochloride with functional groups of amino-containing silica. However, such possibility is needed in an experimental confirmation.

The aim of this work was to investigate the possibility of the direct chemical anchorage of guanidine on the surface of the amino-grafted silica, to study adsorption properties of the synthesized adsorbent with respect to metal ions.

\section{Materials and Methods}

\subsection{Reagents}

Initial solutions with concentration of $1 \mathrm{mg} / \mathrm{ml}$ were prepared by dissolving of precise sample weights of the Analar grade salts $\left(\mathrm{NH}_{4}\right)_{6} \mathrm{Mo}_{7} \mathrm{O}_{24} \cdot 4 \mathrm{H}_{2} \mathrm{O},\left(\mathrm{NH}_{4}\right)_{2} \mathrm{Cr}_{2} \mathrm{O}_{7}, \mathrm{Na}_{2} \mathrm{WO}_{4} \cdot 2 \mathrm{H}_{2} \mathrm{O}, \mathrm{NH}_{4} \mathrm{VO}_{3}, \mathrm{ZnCl}, \mathrm{Pb}\left(\mathrm{NO}_{3}\right)_{2}, \mathrm{CuCl}_{2} \cdot 2 \mathrm{H}_{2} \mathrm{O}$, $\mathrm{Cd}\left(\mathrm{NO}_{3}\right)_{2} \cdot 4 \mathrm{H}_{2} \mathrm{O}$ and $\mathrm{Co}\left(\mathrm{NO}_{3}\right)_{2} \cdot 6 \mathrm{H}_{2} \mathrm{O}$ by method described in [12]. Working solutions were prepared from the initial ones immediately before experiments. The necessary standard solutions of acids and buffers were prepared from appropriate concentrates (FIXANAL ${ }^{\circledR}$, Sigma-Aldrich).

\subsection{Synthesis of Adsorbent}

The Analar grade 3-aminopropyltriethoxysilane, guanidine hydrochloride and absolute toluene were used for synthesis of new adsorbent. Chemical binding of guanidine to the silica surface was carried out in two stages. Silica gel (Merck) with the specific surface area of $256 \mathrm{~m}^{2} / \mathrm{g}$, pore size of $12 \mathrm{~nm}$ and particles diameter of 0.1 $0.2 \mathrm{~mm}$ was used as a carrier.

At the first stage, amino-grafted silica gel was obtained by chemical modification of surface with solution of 3-aminopropyltriethoxysilane in toluene. Initial silica sample $(70 \mathrm{~g})$ was preliminarily dried at $200^{\circ} \mathrm{C}$ for $2 \mathrm{~h}$. Then silica was placed in three-necked round bottom reactor with a thermometer and a reflux condenser and suspended in $250 \mathrm{ml}$ of absolute toluene, then $14 \mathrm{ml}$ of 3-aminopropyltriethoxysilane was added under constant stirring. Reaction mixture was refluxed at the toluene boiling temperature for $2 \mathrm{~h}$. Obtained amino-grafted silica (aminosilica) was then filtered and after 5 times washing with $50 \mathrm{ml}$ toluene and dried under vacuum at $100^{\circ} \mathrm{C}$ $110^{\circ} \mathrm{C}$. The concentration of grafted amino groups $(1.0 \mathrm{mmol} / \mathrm{g})$ was estimated by titrimetry with sodium hydroxide.

At the second stage chemical binding of guanidine hydrochloride was carried out. $20 \mathrm{~g}$ of aminosilica was placed in three-necked round bottom reactor with a thermometer, a reflux condenser, oil bath and mixer and suspended in $30 \mathrm{ml}$ of distilled water, then solution of $1.53 \mathrm{~g}$ ( $0.016 \mathrm{~mol})$ of guanidine hydrochloride in $5 \mathrm{ml}$ of distilled water was added under constant stirring.

The reaction mixture was heated and kept at $70^{\circ} \mathrm{C}-95^{\circ} \mathrm{C}$ for $2 \mathrm{~h}$. Then the temperature was gradually raised to $150^{\circ} \mathrm{C}$ during $3 \mathrm{~h}$, facilitated removal of water. When the reaction mixture had become almost dry, mixer was switched off, but the mixture was kept at temperature of $150^{\circ} \mathrm{C}-160^{\circ} \mathrm{C}$ for $2 \mathrm{~h}$.

The fact of the condensation reaction running and successful binding of guanidine hydrochloride on the aminosilica surface was qualitatively detected by elimination of ammonia and by tracking changes of $\mathrm{pH}$ of the reaction mixture from a weakly alkaline $(\mathrm{pH}=7.3)$ to alkaline $(\mathrm{pH}=8.5)($ Scheme 1$)$. 


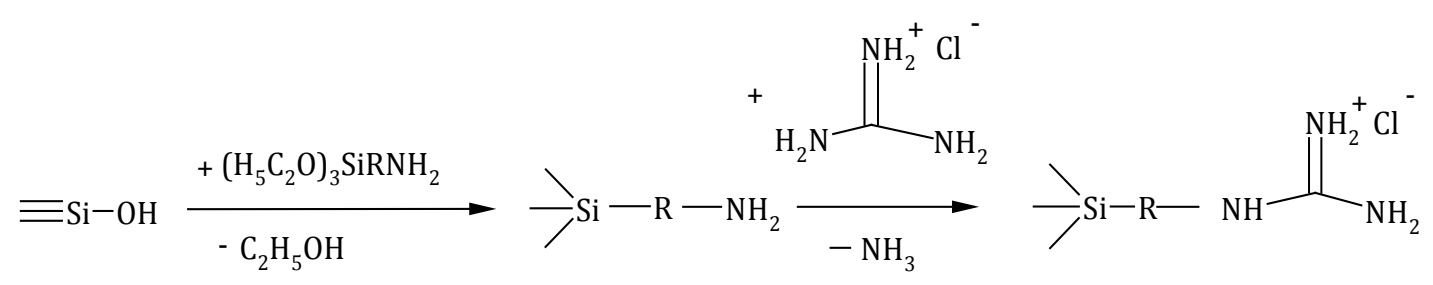

Scheme 1. Covalent binding of guanidine hydrochloride on the surface of modified amino-grafted silica.

\subsection{IR-Spectra}

IR-spectrum of the synthesized adsorbent was investigated and compared with IR-spectrum of guanidine hydrochloride to confirm its covalent binding on the surface of modified amino-grafted silica. Spectra were registered using Nicolet Nexus 470 FT-IR spectrometer. The structure of guanidine hydrochloride is very similar to the structure of amino-grafted silica. However, the characteristic band of $\mathrm{NH}_{2}^{+}$-groups stretching vibrations at $2400 \mathrm{~cm}^{-1}$ is typical for guanidine hydrochloride [13]. This characteristic band is also presented in the IR-spectrum of the synthesized adsorbent, as opposed to the IR-spectrum of amino-grafted silica. This fact also proof successful anchorage of guanidine hydrochloride on aminosilica surface.

\subsection{Concentrations of Bound Polymer}

The concentration of bound guanidine was determined by thermogravimetry.

According to thermogravimetric data the difference in weight loss of the sample between the first and second stage of the synthesis was $7.3 \%$. This weight loss can be attributed to the binding of guanidine hydrochloride on the surface of modified silica. The concentration of chemically bound guanidine hydrochloride, which was calculated from the obtained data, is $75 \mathrm{mg} / \mathrm{g}(0.95 \mathrm{mmol} / \mathrm{g})$ of silica. The degree of conversion of surface aminogroups is $95 \%$.

\subsection{Adsorption of Metal Ions}

The degree of ions adsorption $(R)$ was calculated using the formula:

$$
R=\left(m_{\text {ads }} / m_{o}\right) \cdot 100 \%=\left(m_{o}-m\right) / m_{o} \cdot 100 \%,
$$

where $m_{o}$ is a weight of introduced metal, $m_{a d s}$ is a weight of adsorbed metal, $m$ is a weight of metal in equilibrium solution, calculated as $m=C \cdot V$, where $C$ is an equilibrium concentration and $V$ is an equilibrium volume.

Photometric measurements of equilibrium concentrations $(C)$ of working solutions were conducted using spectrophotometer SF-46 (LOMO, Russia), in a quartz cell with path length of $10 \mathrm{~mm}$ at $540 \mathrm{~nm} \mathrm{for} \mathrm{Cr(VI),} 470$ $\mathrm{nm}$ for Mo(VI), $610 \mathrm{~nm}$ for W(VI), $490 \mathrm{~nm}$ for V(V) and Cu(II), $495 \mathrm{~nm}$ for Zn(II), $520 \mathrm{~nm}$ for Pb(II) and 500 $\mathrm{nm}$ for $\mathrm{Co}(\mathrm{II})$ and Cd(II) according to methods described in [14]-[16]. Standard deviations for all measurements are within $3 \%-4 \%$.

\subsection{Studies of Diffuse-Reflectance Spectra}

Diffuse-reflectance spectra of complexes on modified silica surface were registered using a spectrophotometer Specord-40. Samples of adsorbent $(0.1 \mathrm{~g})$ with previously adsorbed metals were used for these investigations. Concentration of adsorbed metals was 0.5 - $10 \mathrm{mg}$ per $1 \mathrm{~g}$ of a carrier.

\section{Results}

\subsection{Dependence of the Adsorption Degree on the Solution $\mathrm{pH}$}

Studies of adsorption properties of silicas with chemically bound molecules of guanidine hydrochloride were carried out in the static mode. Sample weight $(0.1 \mathrm{~g})$ of modified adsorbent was poured into $25 \mathrm{ml}$ of the solution of salts of the chosen cations and anions with a certain $\mathrm{pH}$ (content of metals for $\mathrm{Mo}(\mathrm{VI}), \mathrm{Cr}(\mathrm{VI}), \mathrm{Zn}(\mathrm{II})$, $\mathrm{Cu}(\mathrm{II}), \mathrm{Cd}(\mathrm{II}), \mathrm{Co}(\mathrm{II})$ and $\mathrm{Pb}(\mathrm{II})-100 \mu \mathrm{g}$, for $\mathrm{V}(\mathrm{V})-300 \mu \mathrm{g}$, for $\mathrm{W}(\mathrm{VI})-1 \mathrm{mg}$ ) and was kept for $24 \mathrm{~h}$ under stirring for determination of a dependence of the adsorption degree on the solution $\mathrm{pH}$. Buffer solutions were 
added to the working solution in a ratio of $1: 5$ (5 ml per $25 \mathrm{ml}$ of working solution). Under such conditions depending on the chemical composition of the buffer, the primary coordination spheres of different chemical nature are formed in the initial solutions of transition metal taken for study, where aqua-, amino-, chloride or citrate ligands dominated. The obtained results are presented in Table 1 and Table 2.

Synthesized adsorbent quantitatively removes $\mathrm{Zn}(\mathrm{II})$ and $\mathrm{Cu}(\mathrm{II})$ cations from distilled water without addition of the buffer solutions. Under these conditions the maximum possible (93\% - 97\%) extraction of $\mathrm{Pb}(\mathrm{II}), \mathrm{Cd}(\mathrm{II})$ and $\mathrm{Co}$ (II) cations is observed. This characteristic of the synthesized chemically modified silica is valuable that would allow extract simultaneously these cations and no additional reagents are required. Also good results for solid-phase extraction of studied ions on the surface of the modified silica are observed in the weakly alkaline medium ( $\mathrm{pH}$ 8.0), i.e. from initial ammonium complexes.

In the highly acidic media, the obtained adsorbent lost adsorption activity with respect to analyzed cations. Under these conditions, nitrogen atoms of polyhexamethyleneguanidine chloride [17] and of monomeric guanidine hydrochloride are protonated, producing a positive charge on the outside surface of the grafted molecules. As a result, electrostatic repulsion between such positively charged sites and cations is increased and the adsorption value decreases. In the alkaline medium, guanidyl groups are transformed into a deprotonated form and behave as usual amino-containing compounds, which can adsorb cations due to the formation of complexes with nitrogen atoms.

Regularities of adsorption of metal-containing oxoanions by synthesized adsorbent also confirm such behavior. The obtained results show that quantitative extraction of $\mathrm{Cr}(\mathrm{VI})$ oxoanions is observed in the acidic medium

Table 1. Dependence of adsorption degree on solution nature and $\mathrm{pH}$ of the medium for extraction of transition metal cations on silica with chemically bound guanidine hydrochloride (quantity of adsorbent $-0.1 \mathrm{~g}$; volume of solution $-25 \mathrm{ml}$; metal content $100 \mu \mathrm{g}$; contact time-24 h).

\begin{tabular}{|c|c|c|c|c|c|}
\hline \multirow{2}{*}{$\begin{array}{c}\mathrm{pH} \\
\text { (medium) }\end{array}$} & \multicolumn{5}{|c|}{ Adsorption, \% } \\
\hline & $\mathrm{Zn}(\mathrm{II})$ & $\mathrm{Pb}(\mathrm{II})$ & $\mathrm{Cd}(\mathrm{II})$ & $\mathrm{Cu}(\mathrm{II})$ & $\mathrm{Co}(\mathrm{II})$ \\
\hline $\begin{array}{c}1.0 \\
\text { (hyrochloric acid) }\end{array}$ & 30 & 0 & 0 & 0 & 0 \\
\hline $\begin{array}{c}1.7 \\
\text { (oxalate buffer) }\end{array}$ & 69 & 0 & 0 & 50 & 39 \\
\hline $\begin{array}{c}4.0 \\
\text { (phthalate buffer) }\end{array}$ & 84 & 18 & 10 & 10 & 0 \\
\hline $\begin{array}{c}6.9 \\
\text { (phosphate buffer) }\end{array}$ & 99 & - & 50 & 70 & 30 \\
\hline (distilled water) & 100 & 93 & 97 & 100 & 95 \\
\hline $\begin{array}{c}8.0 \\
\text { (ammonium-acetate buffer) }\end{array}$ & 100 & 86 & 75 & 99 & 66 \\
\hline
\end{tabular}

Table 2. Dependence of adsorption degree on solution nature and $\mathrm{pH}$ of the medium for extraction of metal-containing oxoanions on silica with chemically bound guanidine hydrochloride (quantity of adsorbent $-0.1 \mathrm{~g}$; volume of solution-25 $\mathrm{ml}$; metal content for $\mathrm{V}(\mathrm{V})-300 \mu \mathrm{g}$, for $\mathrm{W}(\mathrm{VI})-1 \mathrm{mg}$, for $\mathrm{Cr}(\mathrm{VI})$ and $\mathrm{Mo}(\mathrm{VI})-100 \mu \mathrm{g}$; contact time $-24 \mathrm{~h})$.

\begin{tabular}{|c|c|c|c|c|c|}
\hline \multirow{2}{*}{$\begin{array}{c}\mathrm{pH} \\
\text { (medium) }\end{array}$} & \multicolumn{5}{|c|}{ Adsorption, \% } \\
\hline & $\mathrm{W}(\mathrm{VI})$ & Mo(VI) & $\mathrm{K}_{2} \mathrm{Cr}_{2} \mathrm{O}_{7}$ & $\left(\mathrm{NH}_{4}\right)_{2} \mathrm{Cr}_{2} \mathrm{O}_{7}$ & $\mathrm{~V}(\mathrm{~V})$ \\
\hline $\begin{array}{c}1.0 \\
\text { (hyrochloric acid) }\end{array}$ & 100 & 75 & 89 & 89 & 53 \\
\hline $\begin{array}{c}1.7 \\
\text { (oxalate buffer) }\end{array}$ & - & 82 & 99 & 100 & 77 \\
\hline $\begin{array}{c}4.0 \\
\text { (phthalate buffer) }\end{array}$ & 100 & 100 & 28 & 31 & 100 \\
\hline $\begin{array}{c}6.9 \\
\text { (phosphate buffer) }\end{array}$ & - & 0 & 0 & 82 & 77 \\
\hline (distilled water) & 48 & 86 & 0 & 0 & 17 \\
\hline $\begin{array}{c}8.0 \\
\text { (ammonium-acetate buffer) }\end{array}$ & 44 & 94 & 0 & 0 & 77 \\
\hline
\end{tabular}


(pH 1.7), $\mathrm{Mo}(\mathrm{VI})$ and $\mathrm{V}(\mathrm{V})$ oxoanions from the weakly acidic solutions, and full removal of $\mathrm{W}(\mathrm{VI})$ oxoanions is detected in the acidic (pH 1.0) and weakly acidic media.

\subsection{Kinetic Characteristics of Adsorbent}

Conditions of the kinetic adsorption experiments: weight of adsorbent is $0.1 \mathrm{~g}$, the volume of working solution is $25 \mathrm{ml}$, metal content in the initial solution is $100 \mu \mathrm{g}$ ( $5 \mathrm{mg}$ for W). Results of studies of the kinetic characteristics of the synthesized sorbent with respect to each of investigated ions are summarized in Figure 1.

As seen from the obtained data, the quantitative removal of $\mathrm{Cu}(\mathrm{II})$ ions and the maximum possible extraction of $\mathrm{Pb}(\mathrm{II})$ ions occur in a relatively short time (10 minutes). At the same time, the practically quantitative adsorption of $\mathrm{Cd}(\mathrm{II})$ and $\mathrm{Co}(\mathrm{II})$ cations is achieved only for a day. But it is necessary to notice that even for a short time of contact (20 minutes) extraction of the sizable amount of these cations takes place. Thus, the kinetic adsorption characteristics of the obtained adsorbent are similar to the mineral adsorbents.

Adsorption of the major part (80\% - 90\%) of $\mathrm{Cr}(\mathrm{VI})$ and $\mathrm{Mo}(\mathrm{VI})$ oxoanions (Figure 1(b)) occurs for a relatively short time (10 - 20 minutes). Unlike these ions, quantitative extraction of $\mathrm{V}(\mathrm{V})$ oxoanions is achieved much quicker. A more complicated kinetic dependence was observed for adsorption of W(VI) oxoanions.

Synthesized adsorbent shows much better kinetic properties than silica gel with chemically bound polyhexamethyleneguanidine [18]. Thus, chemisorption of guanidine hydrocloride on the aminosilica surface allows one to improve kinetic characteristics of the silica adsorbent with guanidinium groups in the grafted modifying layer.

\subsection{Adsorption Capacity of Synthesized Adsorbent}

For estimation of the adsorption capacity of silicas with chemically bound guanidine the adsorption isotherms of $\mathrm{Pb}(\mathrm{II}), \mathrm{Cd}(\mathrm{II}), \mathrm{Co}(\mathrm{II}), \mathrm{Zn}(\mathrm{II}), \mathrm{Cu}(\mathrm{II})$ cations and $\mathrm{Mo}(\mathrm{VI})-, \mathrm{W}(\mathrm{VI})-, \mathrm{Cr}(\mathrm{VI})-$, and $\mathrm{V}(\mathrm{V})-$ containing anions have been investigated. Experiments were carried out with initial concentration of metals in the solution from $9.6 \times$ $10^{-6}$ up to $3.0 \times 10^{-2} \mathrm{~mol} / \mathrm{L}$. Some of obtained isotherms are represented in Figure 2.

Isotherms of all studied metals belong to the $L$-type, which may indicate a uniform distribution of ligands on the surface of the synthesized adsorbent. In the case of adsorption of transition metals cations, it provides evidence that the similar complexes with active sites of the modified silica surface are formed for these metals.

The values of adsorption capacity of obtained adsorbent estimated from adsorption isotherms are summarized in Table 3.

Obtained experimental results indicated that adsorption capacity of the silica gel with chemically bound guanidine hydrocloride with respect to metal-containing anions lied at the quite high level inherent to the silica gel with chemically bound guanidine-containing polymers [9]. However, unlike carrier with immobilized polymer, the synthesized adsorbent is characterized by 3 - 7 times higher sorption capacity towards transition metal cations. Essential characteristic of the synthesized modified silica is its ability to quantitatively remove microamounts of studied metal ions.

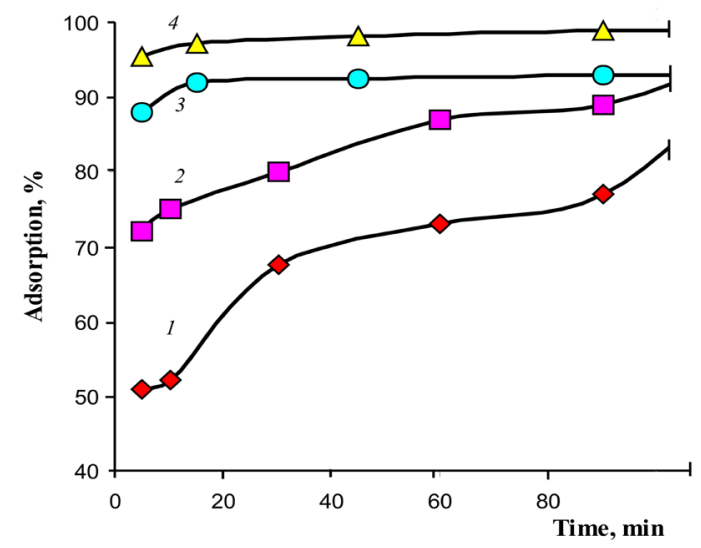

(a)

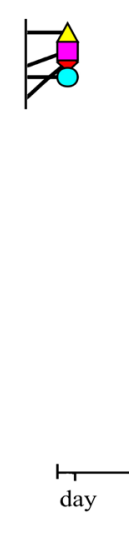

Figure 1. Kinetics of removal: (a) transition metal cations from distilled water: $1-\mathrm{Co}(\mathrm{II}), 2-\mathrm{Cd}(\mathrm{II}), 3-\mathrm{Pb}(\mathrm{II}), 4-\mathrm{Cu}(\mathrm{II})$;

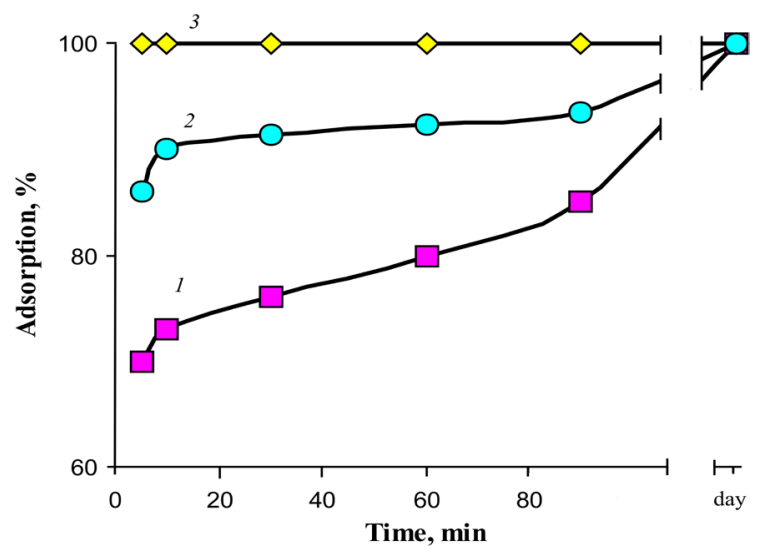

(b) (b) metal-containing oxoanions: $1-\mathrm{V}(\mathrm{V})$ at $\mathrm{pH}=4,2-\mathrm{Cr}(\mathrm{VI})$ at $\mathrm{pH}=1.7,3-\mathrm{Mo}(\mathrm{VI})$ at $\mathrm{pH}=4$ by silica with chemically bound guanidine hydrochloride in the static adsorption mode. 


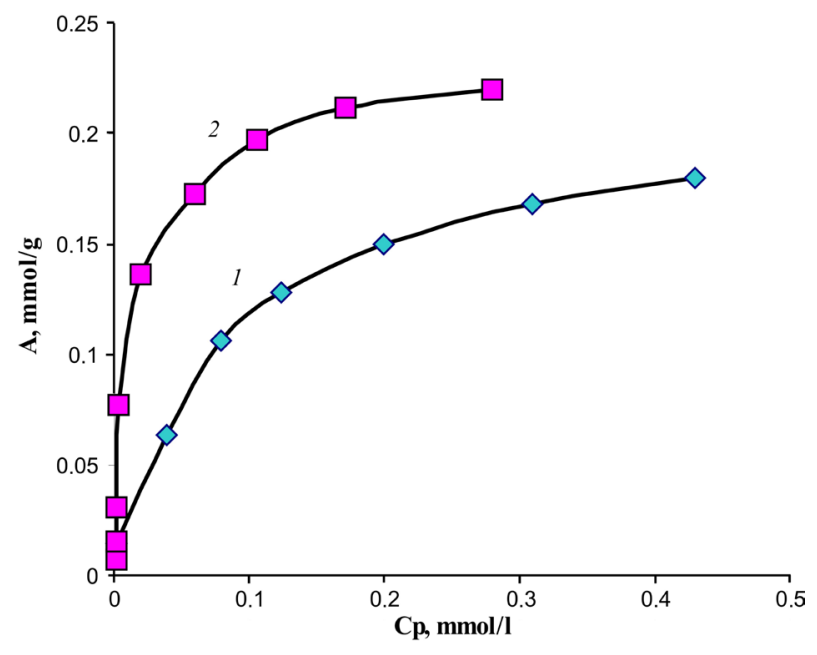

(a)

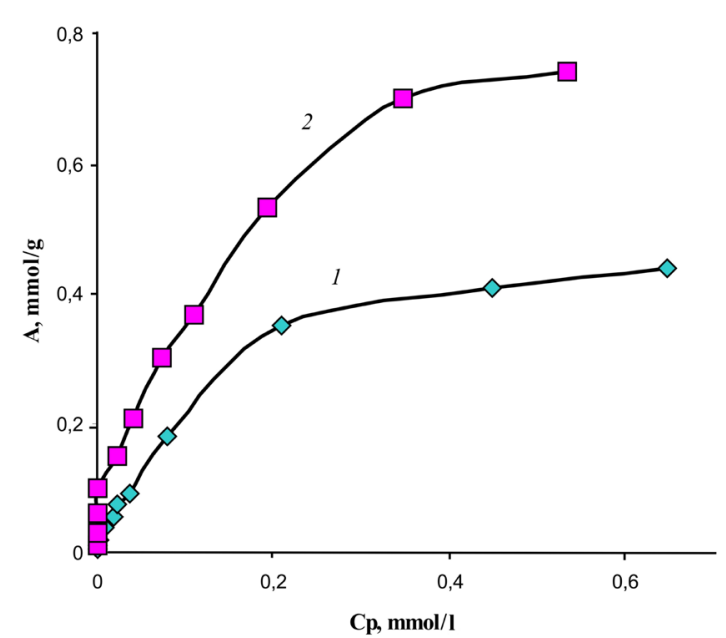

(b)

Figure 2. Adsorption isotherms: (a) cations Zn(II) (1) and Cu(II) (2); (b) oxoanions Cr(VI) (1) and V(V) (2) on silica with chemically bound guanidine hydrochloride.

Table 3. Adsorption capacity of silica with chemically bound guanidine hydrochloride with respect to metal-containing oxoanions and ions of transition metals.

\begin{tabular}{cccc}
\hline Ion & Adsorption capacity, mmol/g & Quantitative extraction, mmol/g & Color of complex \\
\hline $\mathrm{W}(\mathrm{VI})$ & 5.70 & $<0.30$ & white \\
$\mathrm{Mo}(\mathrm{VI})$ & 0.76 & $<0.30$ & pale green \\
$\mathrm{Cr}(\mathrm{VI})$ & 0.44 & $<0.01$ & grey-yellow \\
$\mathrm{V}(\mathrm{V})$ & 0.70 & $<0.10$ & yellow \\
$\mathrm{Co}(\mathrm{II})$ & 0.12 & - & violet \\
$\mathrm{Zn}(\mathrm{II})$ & 0.18 & $<0.02$ & white \\
$\mathrm{Cu}(\mathrm{II})$ & 0.22 & $<0.12$ & light blue \\
$\mathrm{Pb}(\mathrm{II})$ & 0.02 & - & white \\
$\mathrm{Cd}(\mathrm{II})$ & 0.11 & & white \\
\hline
\end{tabular}

\subsection{Spectral Studies of Adsorption Complexes of Metal Ions with Guanidine Hydrochloride Anchored on the Silica Surface}

When studying the adsorption properties of silica with chemically bound guanidine hydrochloride, formation of colored (violet and light blue) complexes of the surface sites with $\mathrm{Co}(\mathrm{II})$ and $\mathrm{Cu}(\mathrm{II})$ cations, respectively, was detected. Electron diffuse-reflectance spectra of the surface complexes with $\mathrm{Co}(\mathrm{II})$ and $\mathrm{Cu}(\mathrm{II})$ cations are presented on Figure 3 and Figure 4, respectively.

As known, pink-colored octahedral aqueous complexes $\left[\mathrm{Co}\left(\mathrm{H}_{2} \mathrm{O}\right)_{6}\right]^{2+}$ with absorption in the region of $500 \mathrm{~nm}$ are formed in aqueous solutions of Co(II) salts. Such characteristic color was also inherent for the working solutions of $\mathrm{Co}$ (II) salts before and during contact with the silica, chemically modified with guanidine hydrochloride. After solid-phase extraction of cobalt ions the light-violet coloration of the adsorbent was observed. Absorption spectra of cobalt compounds, coordinated on the silica surface with chemically bound guanidine hydrochloride, are characterized by three absorbance bands-at $\lambda_{1}=575 \mathrm{~nm}, \lambda_{2}=620-650 \mathrm{~nm}$ and $\lambda_{3}=520-530 \mathrm{~nm}$.

According to [19], the structure of coordinating site for Co(II) ions is changed during binding of these ions with polyhexamethylene guanidine hydrochloride (PHMG) in solution from octahedral, which is characteristic 


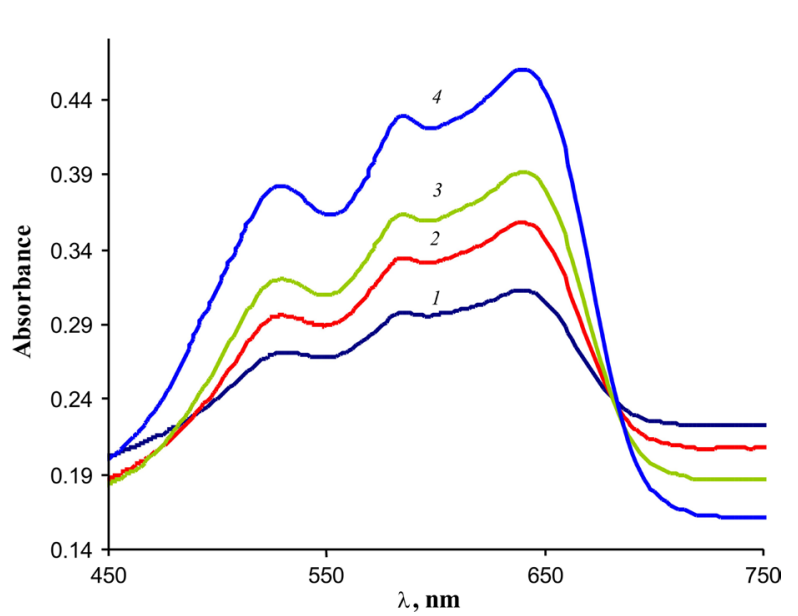

(a)

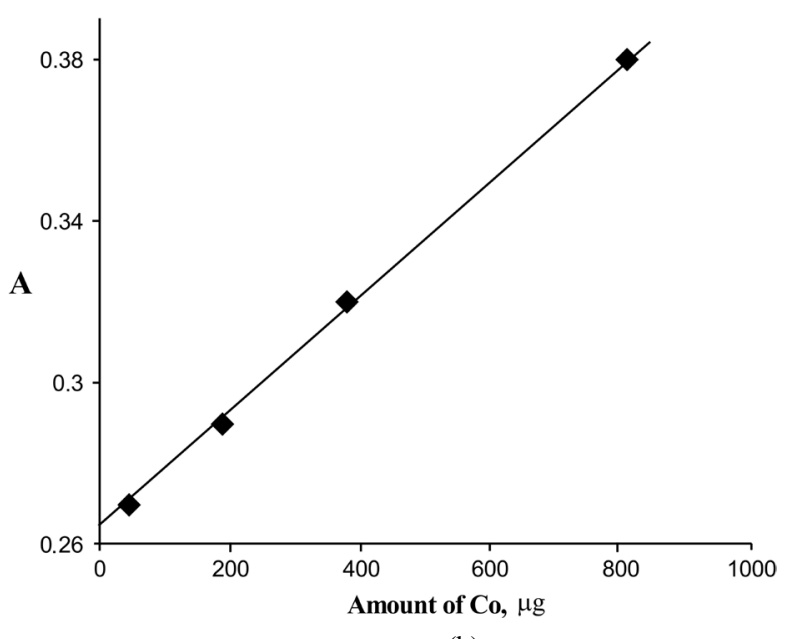

(b)

Figure 3. (a) Electron diffuse reflectance spectra of $\mathrm{Co}(\mathrm{II})$ complexes with guanidine hydrochloride chemically bound to the silica surface for metal contents in samples 430, 1900, 3800 and $8000 \mu \mathrm{g} / \mathrm{g}$ of sorbent (1 - 4 respectively); (b) dependence of absorbance at $\lambda_{\max }=640 \mathrm{~nm}$ in electronic spectra on amounts of cobalt, adsorbed on the surface of silica gel with chemically bound guanidine hydrochloride $(\mathrm{R}=0.999)$.

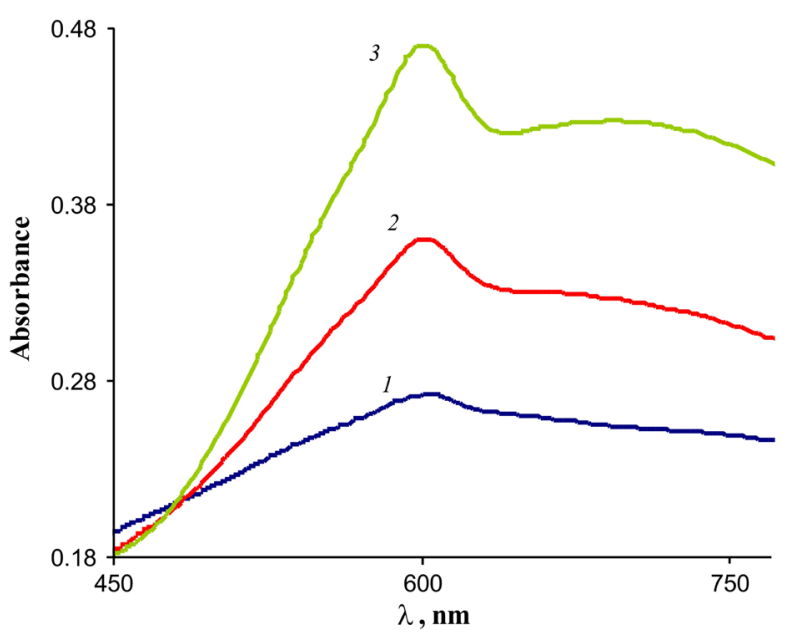

(a)

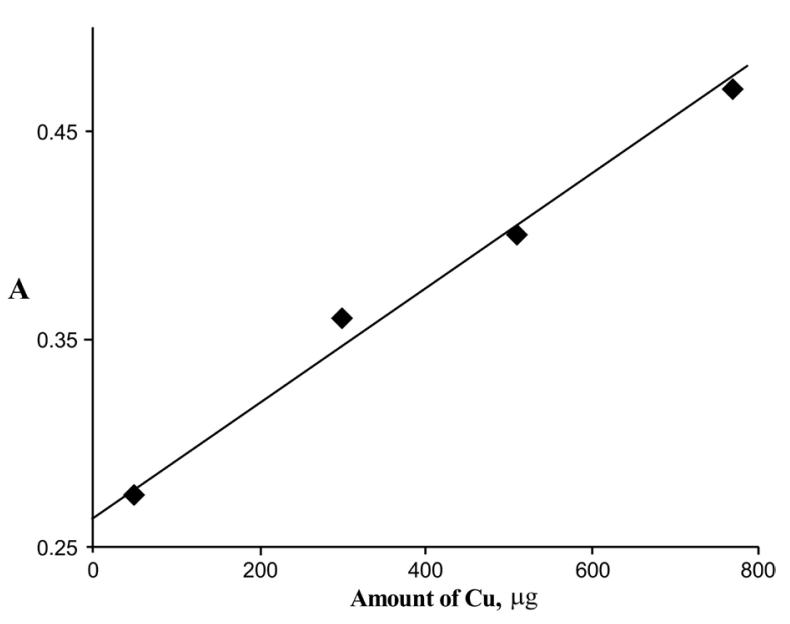

(b)

Figure 4. (a) Electron diffuse reflectance spectra of $\mathrm{Cu}$ (II) complexes with guanidine hydrochloride chemically bound to the silica surface for metal contents in samples $0.5,3$ and $8 \mathrm{mg} / \mathrm{g}$ of sorbent ( 1 - 3 respectively); (b) dependence of absorbance at $\lambda_{\max }=600 \mathrm{~nm}$ in electronic spectra on amounts of copper, adsorbed on the surface of silica gel with chemically bound guanidine hydrochloride $(\mathrm{R}=0.995)$.

for aqueous complexes of cobalt $\left[\mathrm{Co}\left(\mathrm{H}_{2} \mathrm{O}\right)_{6}\right]^{2+}$, to tetrahedral corresponding to formation of the complex with $\left[\mathrm{Co}(\mathrm{PHMG})_{2}\left(\mathrm{H}_{2} \mathrm{O}\right)_{2}\right]^{2+}$ structure (Scheme 2).

Color of the formed compounds, their electronic spectra and literature data [20]-[22] indicate the replacement of aqua-ligands in the primary coordination sphere of $\mathrm{Co}$ (II) by nitrogen atoms of grafted molecules guanidine hydrochloride at metal adsorption with formation on the surface the $\left[\mathrm{CoN}_{2} \mathrm{O}_{2}\right]^{2+}$ tetrahedral complexes, similar in geometry to coordinating site of complexes, described in [21].

Existence of a straight-line correlation between the absorbance values of band at $\lambda_{\max }=640 \mathrm{~nm}$ in diffuse reflectance electronic spectra and the amounts of cobalt, adsorbed on the surface of silica gel with chemically bound guanidine hydrochloride (Figure 3(b)), allows to use this dependence for development of adsorptionphotometric analysis of microamounts of metal ions.

Diffuse-reflectance electronic spectra of $\mathrm{Cu}(\mathrm{II})$ complexes with guanidine are characterized by a maximum absorption at $600 \mathrm{~nm}$ (Figure 4(a)), which is typical for square-planar copper complexes. As in case of Co(II), a 


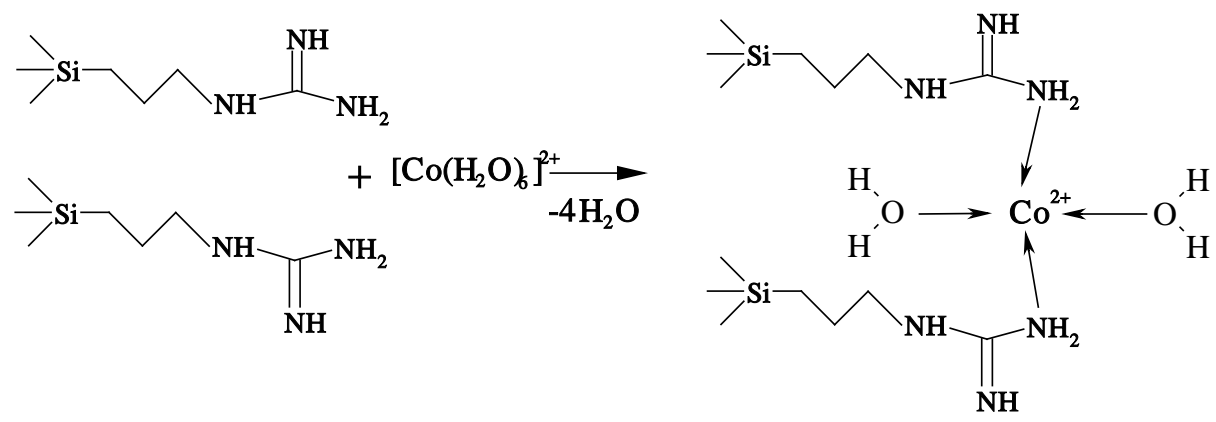

Scheme 2. Complexation of Co(II) ions with active sites of surface of the synthesized adsorbent.

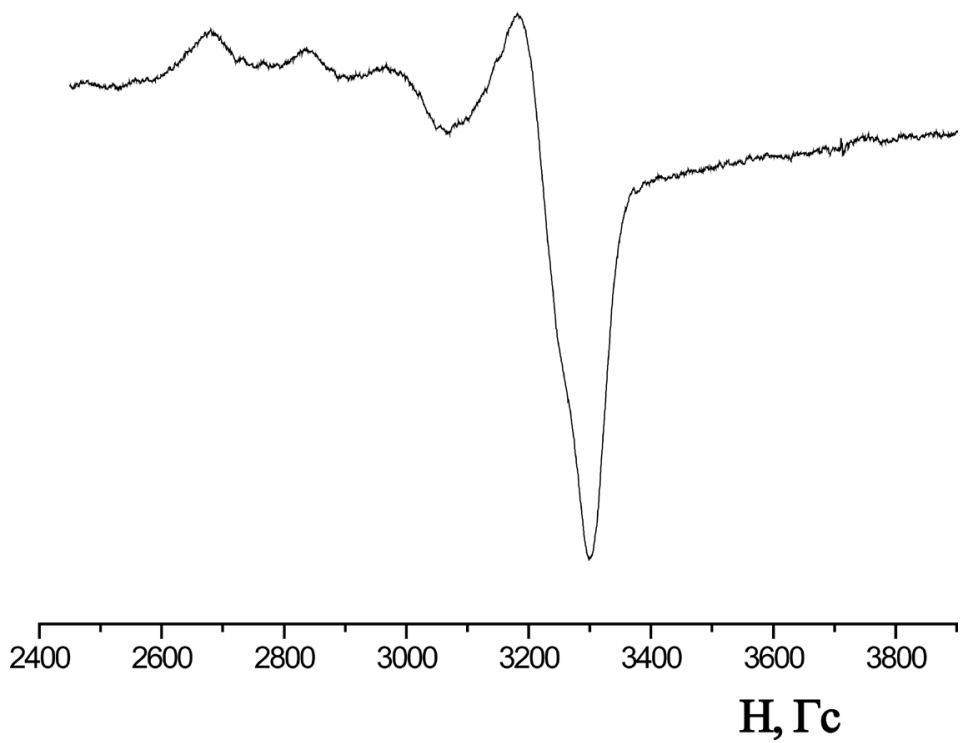

Figure 5. EPR-spectrum of complexes of copper(II) with guanidine hydrochloride chemically bound to the silica surface.

straight-line correlation between the absorbance values of band at $\lambda_{\max }=600 \mathrm{~nm}$ and the amounts of copper, adsorbed on the surface of silica gel with chemically bound guanidine hydrochloride, was established (Figure 4(b)). This dependence may be used to develop a quantitative analysis of microamounts of $\mathrm{Cu}(\mathrm{II})$ ions in the sorbent phase by photometric method.

The EPR-spectrum of complexes of copper(II) ions with guanidine hydrochloride chemically bound to the silica surface (Figure 5) is characterized by $g$-anisotropy and hyperfine structure. This indicates that copper ions on the surface of the modified silica are in a divalent state and confirms considerable mobility of the grafted complexing groups. The spectrum has axially symmetric shape with a split of the hyperfine structure of copper nuclei in the parallel orientation $\left(A_{\|}=140 \times 10^{-4} \mathrm{~cm}^{-1}, g_{\mathrm{II}}=2.308, g_{\perp}=2.069\right)$. Since the anisotropic components of $g$-factor are in the ratio $g_{\mathrm{II}}>g_{\perp}>2.0$, it is possible to affirm that the copper(II) complex has a ground state $d_{x^{2}-y^{2}}$, in other words has square shape [23]. The value of $g_{\mathrm{II}}$ is characteristic for four-coordinated Cu(II) with coordinating site [2N2O]. The coordination takes place through two nitrogen atoms from two ligands and two oxygen atoms from two solvent (water) molecules.

\section{Conclusion}

Adsorbent with a monolayer of chemically bound guanidyl groups was prepared by condensation of guanidine hydrochloride with amino groups of modified silica. Amount of bound ligand was $75 \mathrm{mg} / \mathrm{g}$ of carrier (0.95 $\mathrm{mmol} / \mathrm{g})$. Synthesized adsorbent shows complexing properties and satisfactory adsorption activity with respect to $\mathrm{Pb}(\mathrm{II}), \mathrm{Cd}(\mathrm{II}), \mathrm{Co}(\mathrm{II}), \mathrm{Cu}(\mathrm{II})$ and $\mathrm{Zn}(\mathrm{II})$ ions without addition of any buffer solutions. Silica gel with chemically bound guanidine hydrochloride has well-expressed ion-exchanging characteristics and removes oxoanions 
of $\mathrm{W}(\mathrm{VI}), \mathrm{Mo}(\mathrm{VI}), \mathrm{Cr}(\mathrm{VI})$ and $\mathrm{V}(\mathrm{V})$ from the acidic media. It was found that $\mathrm{Cd}(\mathrm{II})$ and $\mathrm{Cu}(\mathrm{II})$ cations can be quantitatively extracted in the range of initial concentrations up to $5.6 \times 10^{-4} \mathrm{~mol} / \mathrm{l}$. All studied anions can be quantitatively removed in the initial concentration range of metal up to $4 \times 10^{-5} \mathrm{~mol} / \mathrm{l}$, and oxoanions of W(VI) $-1.2 \times 10^{-3} \mathrm{~mol} / \mathrm{l}$. Synthesized modified silica is characterized by good kinetic adsorption characteristics, because removal of $70 \%-80 \%$ of initial concentration of the studied ions and their quantitative extraction for $\mathrm{V}(\mathrm{V})$ and $\mathrm{Cu}(\mathrm{II})$ has been achieved in 10 - 20 minutes. According to electron diffuse reflectance spectroscopy data, $\mathrm{Co}(\mathrm{II})$ ions form with the immobilized ligand, and the surface complexes with tetrahedral structure of coordinating site. According to the results of EPR, $\mathrm{Cu}(\mathrm{II})$ ions form with surface guanidyl groups square-planar complexes. $\mathrm{Co}(\mathrm{II})$ and $\mathrm{Cu}(\mathrm{II})$ complexes on the surface of the synthesized adsorbent can be used for the qualitative and quantitative analyses of microamounts of these metals, because they have a characteristic coloration (violet and light-blue, respectively), that intensities are proportionally increased with the concentration of the adsorbed metal. The straight-line correlations between absorbance of the characteristic bands of these complexes and amounts of the adsorbed metal were detected. These correlations can be used to develop methods of adsorption-photometric analysis of microamounts of cobalt and copper.

\section{References}

[1] Leyden, D.E., Luttrell, G.H., Sloan, A.E. and de Angelis, N.J. (1976) Characterization and Application of Silylated Substrates for the Preconcentration of Cations. Analytica Chimica Acta, 84, 97-108. http://dx.doi.org/10.1016/S0003-2670(01)82843-9

[2] Biernat, J.F., Konieczka, P., Tarbet, B.J., Bradshaw, J.S. and Izatt, R.M. (1994) Complexing and Chelating Agents Immobilized on Silica Gel and Related Materials and Their Application for Sorption of Inorganic Species. Sep. Purif. Methods, 23, 77-348. http://dx.doi.org/10.1080/03602549408006624

[3] Zaitsev, V.N. (1997) Complexing Silica: Synthesis, Structure of the Grafted Layer and Surface Chemistry, Pholio, Khar'kov.

[4] Huang, X., Chang, X., He, Q., Cui, Y., Zhai, Y. and Jiang, N. (2008) Tris(2-aminoethyl) amine Functionalized Silica Gel for Solid-phase Extraction and Preconcentration of $\mathrm{Cr}(\mathrm{III}), \mathrm{Cd}(\mathrm{II})$ and $\mathrm{Pb}(\mathrm{II})$ from Waters. Journal of Hazardous Materials, 157, 154-160. http://dx.doi.org/10.1016/j.jhazmat.2007.12.113

[5] Pereira, A.S., Ferreira, G., Caetano, L., Martines, M.A.U., Padilha, P.M., Santos, A. and Castro, G.R. (2010) Preconcentration and Determination of $\mathrm{Cu}(\mathrm{II})$ in a Fresh Water Sample Using Modified Silica Gel as a Solid-Phase Extraction Adsorbent. Journal of Hazardous Materials, 175, 399-403. http://dx.doi.org/10.1016/j.jhazmat.2009.10.018

[6] Ekinci, C. and Köklü, Ü. (2000) Determination of Vanadium, Manganese, Silver and Lead by Graphite Furnace Atomic Absorption Spectrometry after Preconcentration on Silica-gel Modified with 3-aminopropyltriethoxysilane. Spectrochimica Acta Part B: Atomic Spectroscopy, 55, 1491-1495. http://dx.doi.org/10.1016/S0584-8547(00)00259-7

[7] Zolotov, Yu.A., Tsysin, G.I., Morosanova, E.I. and Dmitrenko, S.G. (2005) Sorption Preconcentration of Microcomponents for Chemical Analysis. Russian Chemical Reviews, 74, 37-60. http://dx.doi.org/10.1070/RC2005v074n01ABEH000845

[8] Tertykh, V.A., Polishchuk, L.M., Yanovska, E.S. and Dadashev, A.D. (2008) Concentration of Anions by Silica Adsorbents with Immobilized Nitrogen-containing Polymers. Adsorption Science \& Technology, 26, 59-68. http://dx.doi.org/10.1260/026361708786035350

[9] Dadashev, A.D., Tertykh, V.A., Yanovska, E.S. and Yanova, K.V. ( 2012) Ion-Exchange Properties of Modified Silicas with Bound Amides of Polyhexamethyleneguanidine and Maleic or o-Phthalic Acids with Respect to MetalContaining Anions. Chemistry, Physics and Technology of Surface, 3, 419-428.

[10] Dadashev, A.D., Tertykh, V.A., Yanovska, E.S., Ryabchenko, K.V., Yanova, K.V. and Kutyanina, V.S. (2010) Sorption of Transition Metals by Silica Gel with bound Amide of Maleic Acid and Polyhexamethyleneguanidine on the Surface. Russian Journal of Applied Chemistry, 83, 2110-2114. http://dx.doi.org/10.1134/S1070427210120086

[11] Khokhlov, A.R., Pavlova, S.-S.A., Timofeeva, G.I., Stoljarova, E.V., Bazaron, L.U., Topchiev, D.A., Gembitsky, P.A. and Boksha, L.F. (1994) Three-Dimensional Polycondensation of Monomers with Ionomer-Type Interactions. Polymer, 35, 1769-1773. http://dx.doi.org/10.1016/0032-3861(94)90854-0

[12] Korostylev, P.P. (1964) Preparation of Solutions for Chemical-Analytical Work. Nauka, Moscow.

[13] Gordon, A.J. and Ford, R.A. (1972) The Chemist’s Companion. Wiley-Interscience, New York.

[14] Marchenko, Z. and Balcerzak, M. (1998) Spectrofotometryczne Metody w Analizie Nieorganicznej. Wydawnictwo Naukowe PWN, Warszawa.

[15] Busev, A.I., Ivanov, V.M. and Sokolova, T.A. (1976) Analytical Chemistry of Tungsten. Nauka, Moscow. 
[16] Shcherbov, D.P. and Matveets, M.A. (1973) Analytical Chemistry of Cadmium. Nauka, Moscow.

[17] Gembitskii, P.A. and Vointseva, I.I. (1998) Polymeric Biocidic Preparation of Polyhexamethyleneguanidine. Poligraph, Zaporozh'e.

[18] Dadashev, A.D., Yanovska, E.S. and Tertykh, V.A. (2009) Application of Silica with Grafted Polyhexamethyleneguanidine Hydrochloride in Concentration and Determination of Transition Metal Cations and Metal-containing Anions. Naukovi zapysky NaUKMA, khim. nauky i tekhnol., 92, 23-27.

[19] Nyzhnik T.Y. (2007) The Extraction of Heavy Metal Ions from the Water Solution with Usage of Nitrogen-containing Polymeric Reagent. Ph.D. Thesis, National Technical University of Ukraine “Kyiv Polytechnic Institute”, Kyiv.

[20] Skopenko, V.V. and Zub, V.Ya. (2002) Coordination Chemistry. Practicum, Kyiv University, Kyiv.

[21] Skopenko, V.V., Trofimchuk, A.K. and Zaitsev, V.N. (1982) Investigation of Interaction Between Non-Aqueous Solutions of $\mathrm{Cu}(\mathrm{II})$ and $\mathrm{Co}(\mathrm{II})$ and $\gamma$-(2(8)-Methylquinoline)aminopropylaerosil. Zh. Neorg. Khim., 27, 2579-2585.

[22] Zaitsev, V.N., Skopenko, V.V. and Trofimchuk, A.K. (1984) Stereochemistry of Coordination Compounds of Co(II) and $\mathrm{Cu}(\mathrm{II})$, Bound on Surface of Modified Aerosils. Zh. Neorg. Khim., 29, 1222-1226.

[23] Skopenko, V.V., Zub, V.Ya., Fritskii, I.O. and Lampeka, R.D. (2008) Experimental Methods in Coordination Chemistry. Kyiv University, Kyiv. 